\title{
Agata Kusto
}

Uniwersytet Marii Curie-Skłodowskiej w Lublinie

LEGOWANIE NA LUBELSZCZYŹNIE. WSPÓLCZESNE ODKRYCIA I KONTYNUACJE LOKALNEJ PRAKTYKI MUZYCZNEJ

Ligawa należy do instrumentów o najdłuższej udokumentowanej historii istnienia na ziemiach polskich. I choć sama nazwa „ligawka” nie widnieje w literaturze przed XVIII wiekiem to jako rodzaj instrumentu, drewnianego aerofonu ustnikowego, ma poświadczenie od czasów formowania się państwowości polskiej (Dahlig 2003:39). Instrumentologicznie ligawa należy do grupy aerofonów, zwanych zwykle instrumentami dętymi. W systematyce polskiej znajdziemy nazwę trąba, którą od trąbki odróżniać będzie długa prosta rura o lekko konicznym przekroju. Dodatkowo, w grupie tej znajdują się także rogi, które winny kształtem wskazywać na pochodzenie od rogów zwierzęcych, ale ta nazwa także widnieje w literaturze określającej dzisiejszą ligawę (Sachs 1989:432). Włodzimierz Kamiński opisując okres wczesnego średniowiecza przywołuje zapisy kronikarskie z końca X wieku (niem. kronikarz Thietmar), w których wspomina się o używaniu trąb w wojskach słowiańskich podczas bitwy nad Tongerzą, zaś Wincenty Kadłubek posługuje się terminem tuba, opisując krakowskie widowisko w roku 1194. Kamiński owym trąbom przypisuje te same cechy, które nosi dzisiejsza grupa rogów. W ikonografii średniowiecznej istniały dwa typy rogów: rogi bydlęce używane wyłącznie w praktyce myśliwskiej do sygnalizacji (zwykle opatrywane nazwą cornu). Drugim typem były instrumenty budowane z drewna (opisywane łac. nazwą tuba). Sposób ich wyrobu uprawdopodabnia Kamiński na podstawie współczesnej praktyki wyrobu trembit, polegającej na rozcinaniu pnia młodego drzewka wzdłuż osi na dwie połowy i po wydrążeniu ich na złożeniu za pomoca wiązania $\mathrm{z}$ mokrego łyka bądź założenia metalowych obręczy. O ile tego rodzaju instrumenty muzyczne pochodzące $\mathrm{z}$ wczesnego średniowiecza nie dotrwały do naszych czasów, o tyle ważnym elementem stał się drewniany ustnik, odnaleziony podczas badań archeologicznych na Wolinie. To pozwoliło Kamińskiemu na wysnucie hipotezy, że „współczesna ligawka i jej regionalne warianty pochodzą $\mathrm{w}$ prostej linii od tamtych trąb wczesnośredniowiecznych, które w tradycyjnej praktyce ludowej przetrwały w niezmienionej formie do naszych czasów"(Kamiński 1971: 47-48).

Funkcjonowanie tego typu instrumentów na ziemiach polskich jest uwarunkowane regionalnie. Tradycja mazowiecko-podlaska, najbardziej pokrewna co do kontekstu i obszaru występowania tradycji lubelskiej wiąże się ze zwyczajem otrębywania adwentu. W takiej formie została udokumentowana na terenach Mazowsza Leśnego (wschodnie, po prawej stronie Wisły) i Mazowsza Starego (północne), przy czym główny obszar występowania nazwy instrumentu sytuuje Dahlig w części prawobrzeżnej historycznej dzielnicy Mazowsza oraz północnej części Ziemi Sandomierskiej, należącej do współcześnie rozumianej Lubelszczyzny (Dahlig 2003: 66-67). Obecność tego instrumentu na obszarze dzisiejszej Lubelszczyzny, bądź w bezpośrednim jej sąsiedztwie dokumentowana jest dopiero od II poł. XX wieku. Za incydentalny przekaz z okresu międzywojennego należy uznać pieśń Guń krówki, guń zapisaną w 1937 r. przez Waleriana Batkę (Chmara 1937: 52). Przed rokiem 1982 Jadwiga Sobieska w omawianej grupie aerofonów ustnikowych przypisuje nazwy „ligawki” albo „ligawy” do Mazowsza i Puszczy Białej, zaś „legawki” albo „legawy” do Podlasia i Lubelszczyzny. Podaje, że:

instrumenty te sporządzone są z dwóch połów odpowiednio wybranego i przeciętego wzdłuż pnia (lub gałęzi) młodej sosny, olchy albo lipy. Po usunięciu rdzenia i wyżłobieniu kanału, składa się 
obie połowy i spaja różną techniką.(...) nakłada się obręcze z blachy żelaznej lub wikliny. Instrumenty uszczelnia się smołą. Technika gry polega na wykorzystaniu szeregu dźwięków przedętych, które pozwalają na wygranie zwrotów melodycznych. (...) Ligawki w rękach pastuchów sygnalizowały spęd bydła na wypas wiosenny, a zimą, w okresie adwentu, przypominały o sprawach ducha i zwoływały wiernych na roraty o szarej, rannej godzinie. (...) bazuny i ligawki były krótsze, 120-180 cm (Sobieska 2006: 99-100).

Powyższy opis zamieszczony na potrzeby skryptu o przeznaczeniu edukacyjnym nie zawiera odniesień do konkretnych eksponatów ani źródła informacji. Można przypuszczać, że powstał on po ekspozycji polskich ludowych instrumentów muzycznych, zorganizowanej przez Centralę Handlową Przemysłu Muzycznego a odbywającej się w dniach od 16 IX do 16 X 1966 roku w gmachu PWSM w Warszawie. Marian Sobieski, obok tak znaczących dla polskiej kultury instrumentów skrzypcowych i dudowych, docenia znaczenie prostych aerofonów:

Wzdłuż powiślańskich brzegów macierzystej Wisły, od Puław po dorzecze Narwi, trąbi się wieczorami na zakrzywionych drewnianych ligawach, które dziś jeszcze gęsto obsiadły pola mazowszańskie. Ich smętny, donośny głos symbolizuje porę spędu bydła, a w mroźną zimę zapowiada czas adwentu i godzinę porannych rorat (Sobieski 1973: 170).

W zamieszczonym tam wykazie instrumentów ludowych, w grupie instrumentów dętych wargowych z ustnikiem kociołkowatym (trąbkowe) znalazła się pod numerem 11 ligawa lubelska ze wsi Celejów, gm. Wąwolnica (Sobieski 1973: 177). W tejże miejscowości 21 marca 1959 roku Marian Sobieski nagrał grę na ligawie nieznanego wykonawcy. Nagranie to opatrzone opisem: „Nagranie w plenerze dokonane przez Mariana Sobieskiego w 1959 r., sygnatura zbiorów fonograficznych IS T 2569" zamieszcza wraz z transkrypcją P. Dahlig (Dahlig 2003: 232). Najprawdopodobniej wykonawcą był Józef Ochal ur. 1917 w Drzewcach (gm. Nałęczów). Ochal znany był z wyrobu tych instrumentów i z gry na nich, co wówczas było powszechną praktyką. Instrument wykonany przez Józefa Ochala znajduje się w zbiorach prywatnych Zenona Kotera i został odnotowany w opisie instrumentów w tomie lubelskim pod numerem 44 (Koter, Kusto 2011: 48). W czasie adwentu dźwięki ligawy roznosiły się po okolicznych miejscowościach. Józef Ochal grał w Celejowie (gm. Wąwolnica), Ludwik Rusek w leżącym nieopodal Stoku (gm. Końskowola), zaś w Karmanowicach (gm. Wąwolnica) legował Jan Koter (ur. 1905 r. w Karmanowicach), także wykonawca ligaw. Zenon Koter (syn Jana Kotera) wspomina, że legacze „,przegrywali do siebie”, czyli wygrywali własne melodie $\mathrm{w}$ tym samym czasie $\mathrm{w}$ różnych miejscach, co tworzyło szczególny efekt brzmieniowy w przestrzeni kilku kilometrów (Koter 2018).

W latach 1958-1971 Janina Petera prowadziła badania nad lubelską obrzędowością dla Muzeum Lubelskiego w Lublinie i Muzeum Wsi Lubelskiej. Ustaliła, że w wielu miejscowościach Powiśla Lubelskiego (wśród nich także kilka miejscowości oddalonych na wschód od Powiśla), tj. we wsiach Gołąb, gm. Puławy, Gutanów, gm. Garbów, Kaliszany, gm. Józefów n. Wisłą, Klementowice, gm. Kurów, Nasiłów, gm. Janowiec, Piotrawin, gm. Łaziska, Sieprawice, gm. Jastków i Wronów, gm. Bełżyce, praktykowana była adwentowa gra na ligawce, którą wykonywano z drzewa lipowego lub wierzbowego. Grano przed wschodem i zachodem słońca, a grającymi byli młodzi chłopcy. Według starszych informatorów gra na ligawce miała przypominać o końcu świata i trąbieniu Archanioła na Sądzie Pańskim (Petera 1986: 16-17). Jak podaje za Krystyną Komstą Janina Petera zwyczaj grania na ligawkach zanotowano także w Michałówce, gm. Abramów, gdzie tamtejszy mieszkaniec, Henryk Duda tak wspominał ów zwyczaj: 
Na lygawkach grały. To już tam wyrobiały lygawki, przysykowywały sia. Już jak nadchodził adwent. $Z$ wirzbowego drzewa ta lygawka była. Gałuź taku sobie wziun, wydłuboł w środku, "ostrugano była, wydłubano ładnie i na końcu była, taki miała zasadzuny, taki copek i to grało. Jak kto "umioł grać, to to tak piãknie wygrywoł, ze nie pojancie w adwencie, bo w adwencie kiedyś nie było zabaw, tylko na tych lygawkach, na tu pamiuntka, ze sia mioł narodzić Pan Jezus, to grały na lygowkach (Komsta 1980).

Poświadczenia gry na ligawie szły w parze z pozyskiwaniem instrumentów dla Muzeum Lubelskiego w Lublinie oraz Muzeum Wsi Lubelskiej. W latach 1951-1981 dla obu muzeów pozyskano lub zakupiono siedem instrumentów z miejscowości: Opoka, gm. Końskowola, Chrząchówek, gm. Końskowola, Klementowice, gm. Kurów i Gutanów, gm. Garbów (Koter, Kusto 2011: 49-50). W roku 1957 pozyskano dla Muzeum Lubelskiego ligawę ( $\mathrm{nr}$ inw. 4990/E/ML) nieznanego wykonawcy z Gutanowa, do której kartę inwentarzową wypełniła Teresa Karwicka podając, że ligawka była wykonana $\mathrm{z}$ drzewa topoli i złożona $\mathrm{z}$ dwóch części spojonymi obręczami z drutu. Prócz wymiarów odnotowała, że ,grają na nich do dziś dnia w okresie adwentu. Dawniej grali pasterze" oraz cytuje wiersz napisany przez Bronisława Pietraka Na ligawce:

Narodzenie adwent głosi,

świąt wygląda wierny lud, młody chłopiec na ligawce gra do Gód, aby do Gód.

Droga dla nas ta tradycja, z nią też zżył się wiejski lud. Co dzień z rana i z wieczora słychać granie - aby do Gód.

Wiatr na dworze śniegiem prószy, na ligawce obmarzł lód, a przed chatą młody chłopiec gra do Gód, aby do Gód.

Syn po ojcu na ligawce gra melodię tę bez nut, a po wiosce echo płynie, aby do Gód, aby do Gód.

Nie zaginie ta tradycja, dokąd żyje wiejski lud i grać będziem tak co roku, aby do Gód, aby do Gód (Petera 1986: 16-17).

Wielce prawdopodobne, że to właśnie autor wiersza, Bronisław Pietrak mógł być wykonawcą ligawki znajdującej się w zbiorach Muzeum Lubelskiego. Inny instrument wykonany przez niego można oglądać na wystawie stałej Muzeum Etnograficznego im. Seweryna Udzieli w Krakowie. Został pozyskany za pośrednictwem Zofii CieślaReinfussowej w roku 1968, a w karcie inwentarzowej widnieje informacja o tym, że był używany w adwencie rano a informacja ta pochodzi z karty inwentarzowej, udostępnionej przez kustosza Muzeum Etnograficznego im. Seweryna Udzieli w Krakowie, p. Karolinę Pachlę-Wojciechowską. Miejscowość Gutanów ma też inne poświadczenia gry na ligawie. Joanna Malinowska w swojej pracy magisterskiej na temat ligawy zamieszcza zdjęcie Bronisława Skoczylasa z Gutanowa grającego na ligawie. W czasie, kiedy autorka przeprowadzała badania terenowe instrument nieznanego wykonawcy datowany 
na ok. 1897 r. był w posiadaniu mężczyzny uwidocznionego na zdjęciu (Malinowska 1997: 48). Z Gutanowa pochodzi także ligawa (nr inw. PME 10250) pozyskana przez Ministerstwo Kultury i Sztuki a przekazana w 1958 roku Państwowemu Muzeum Etnograficznemu w Warszawie (Lewińska 2001: 154, 261). Kolejna, pochodzi z Woli Przybysławskiej (gm. Garbów) i znajduje się w Muzeum Ludowych Instrumentów Muzycznych w Szydłowcu (Dahlig 2003: 63).

W roku 1959, na łamach ogólnopolskiego miesięcznika krajoznawczoturystycznego „Poznaj Swój Kraj” Teresa Karwicka pisząc o wybranych obrzędach dorocznych lubelskiej wsi wspomina o poprzedzającym okres Bożego Narodzenia adwencie, kiedy to

codziennie rano i wieczór grają chłopcy na długich ligawkach z drzewa topolowego. Robi się je z dwóch półokrągłych połówek drewna, które spaja się obręczami drucianymi lub z blachy. Głos ligawki niesie się daleko $\mathrm{w}$ mroźnym powietrzu, a brzmi szczególnie dobrze, gdy ligawkę zamoczoną w wodzie wystawi się na mróz, by obmarzła. Zwyczaj ten znany jest tylko w północnych częściach Lubelszczyzny, głównie w powiecie puławskim i na Podlasiu (Karwicka 1959: 10).

Bogate tradycje legowania na Podlasiu, szeroko zostały opisane w przywoływanej publikacji Piotra Dahliga jak i w tomie podlaskim PPML, gdzie Janina Szymańska przywołuje informacje zebrane w 1951 r. w miejscowości Ostrówki, gm. Wohyń:

Młodzi chłopcy, a i dorośli mężczyźni, wybierali się po pierwszym mrozie do lasu i wybierali starą sosnę, a z jej wyciętej, długiej gałęzi, najlepiej dwumetrowej, wyrabiali ligawki. Zdejmowali korę, przecinali gałąź na pół, wydłubywali środek i dwie wydrążone połówki składali, umacniali łykiem, dla lepszego głosu zanurzali w wodzie, by zamarzła, i w mgliste poranki lub wczesne wieczory wychodzili przed domy i przeciągłym graniem na nich oznajmiali, że Bóg narodzi się, że przyjdzie na świat niedługo. Trąbiono od dwudziestego września do późnych zazimek. Instrument ten zrobiony z sosnowej skrzekowatej gałęzi. Długości około 1 metr $40 \mathrm{~cm}$. Grubość obwodu na zewnątrz $40 \mathrm{~cm}$. W cieńszym końcu, gdzie munsztuk osadzony z bzu świętojańskiego, $18 \mathrm{~cm}$. Klepki nabite witkami dartemi na pół. Głos tej trąby słyszany na $5 \mathrm{~km}$. Melodia miła i wzruszająca. Na tę nutę śpiew:

Żeń woły, żeń, już biały dzień,

żeń woły pszenicą, niech woły nie ryczą,

już woły przy bagnie, a Kuba przy Jagnie (Szymańska 2016: 156-157).

Tradycje Podlasia Południowego będącego pasem „wspólnym” Podlasia i Lubelszczyzny w sposób naturalny przenosiły się na tereny północnej Lubelszczyzny, gdzie udało się udokumentować najwięcej przejawów związanych $\mathrm{z}$ adwentowym legowaniem. Jednakże usytuowanie legowania potwierdzają także przekazy z gmin Poniatowa i Bełżyce. Miejscowość Wronów wykazała w swoich badaniach Janina Petera, zaś w pobliskiej Dąbrowie Wronowskiej mieszkał Stefan Wrona (ur. 1929, Komarzyce), skrzypek, członek kapeli Stefany, który podczas badań przeprowadzonych dla UMCS w 1993 r. potwierdził obecność ligawki w czasie adwentu, jako jedynego instrumentu, którego dźwięk był słyszalny w czasie, gdy „zanikło wszystko, zabaw nie było, ani nic" (Wrona 1993).

Kolejne poświadczenia obecności ligawy na Lubelszczyźnie uzyskano w latach 2008-2009 podczas terenowych badań uzupełniających do tomu lubelskiego w ramach serii PPML i wiązały się one $\mathrm{z}$ przesunięciem granic występowania zwyczaju. Wówczas przeprowadzono wywiad z Władysławem Majem ze Sporniaka, gm. Wojciechów, wieloletnim bębnistą Kapeli Wojciechowskiej. Na ligawie grał w czasie wojny i po wojnie, do końca lat 80 . XX w. Grał tylko w adwencie, codziennie o godzinie 6 rano i 6 
wieczorem. Władysław Maj wchodził na podwyższenie zrobione z kilku ułożonych piętrowo opon samochodowych, opierał ligawę o drewnianą konstrukcję, kierując wylot instrumentu w stronę rozległego pasa pól zakończonego lasem. Podczas gry na ligawie dźwięk odbijał się od ściany lasu. Władysław Maj miał w posiadaniu dwie ligawy o pochodzeniu lubelskim:

1. Ligawa drewniana z drewna lipowego, początkowo była wiązana wikliną, później drutem. Otrzymana od dziadka, Mateusza Maja, który sam ją wykonał. W czasie badań w roku 2008 instrument posiadał 10 obręczy drucianych, ustnik drewniany ze szpuli do nici (Koter, Kusto 2011: 47). Obecnie instrument ten zaginą. Wnuk Waldemar przechowuje ligawę, którą w 2008 roku Władysław Maj określał jako nabytek nie lubelskiego pochodzenia.

2. Ligawa metalowa, ocynkowana, wykonana przez Antoniego Wilczka, blacharza z Bełżyc w latach 40. XX w. Na tym instrumencie Władysław Maj grał najwięcej bo wydawała najlepszy dźwięk. Ten wyjątkowo długi jak na ligawy instrument $(183 \mathrm{~cm})$, zaopatrzony w metalowy ustnik kornetowy zapewniał łatwość gry i nośność dźwięku. Według Maja słyszalność gry dochodziła do 8 kilometrów. Fraza muzyczna przerywana była braniem oddechu, po czym następowało kilkakrotne powtórzenie schematu. $\mathrm{Na}$ tę melodię śpiewano Aby do Gód, aby do Gód, co oznaczało oczekiwanie Świąt Bożego Narodzenia. Według Władysława Maja we wsi nikt inny nie grał na tym instrumencie a informacja ta została wkrótce zrewidowana (Maj 2008).

Wzmianki o praktyce gry na ligawie w Motyczu znajdziemy w wypowiedziach i spisanych wspomnieniach Czesława Maja (ur. 1923, Motycz), poety ludowego, regionalisty i założyciela Zespołu Ludowego „Rola” w Motyczu. Dla Archiwum Programu Historii Mówionej Teatru NN poeta przywołał opowieść biblijną, tłumaczącą zwyczaj grania na ligawie:

No to ja się pytałem starych ludzi: co to znaczy, to granie, tego? No to mówili, że «Ligawa wtóruje - święta wywołuje». Że to po graniu ligawy święta będą zaraz. Ale jeszcze było tak, że do Starego Testamentu ludzie sięgali. Pan Bóg polecił prorokowi Jonaszowi, żeby udał się do miasta Niniwy i tam żeby nawracał ludzi, bo strasznie grzeszne to miasto było. Ale tam słyszał ten prorok, że oni nie dbaja o nic - zabijają nawet ludzi jak kto przychodził ich poprawić. I wsiadł na okręt i pojechał w dół i koniec. W przeciwnym kierunku. I zerwała się burza na morzu. Okręt zatonął. A tego Jonasza połknęła ryba. I trzy dni był we wnętrzu ryby, a później ryba go wyrzuciła i on żył jeszcze. I poszed jednak do tego miasta - już co będzie. Ale ci Niniwianie się śmiali z niego. A on w końcu wziął dwa garnki gliniane i na rynku w Niniwie stłukł te garnki. I mówi: «Tak Pan Bóg was zetrze, jak ja te garnki stłukłem». No i oni sobie wzięli do serca to i zaczęli pokutować. Posypali głowy popiołem, wory pokutne przywdziali. I właśnie nawet król dał takie zarządzenie, że bydłu nie dawać jeść przez ileś tam dni, żeby ryczało, żeby prosiło Boga i to bydło o zmiłowanie. No i, tak że, to pomogło, że ci Niniwianie się nawrócili. Że stąd właśnie ta ligawa, że to bydło ryczało (Lasota 2011)

Czesław Maj pamiętał, jak w przeszłości w czasie adwentu dźwięk ligaw dochodził z kilku miejsc jednocześnie „,bo tu kilku umiało grać”. Pierwsze granie odbywało się w pierwszą niedzielę adwentu a niektórzy wstawali jeszcze w nocy aby grać. Najlepiej było grać kiedy był przymrozek i wówczas głos ligawy był dobrze słyszalny (Lasota 2011).

Przerwę w otrębywania adwentu w gminie Konopnica można usytuować od końca lat 80. (wówczas grał jeszcze Władysław Maj na Sporniaku) do ok. roku 2010. Po śmierci Władysława Maja blaszana ligawa została odkupiona przez sąsiada, Tadeusza Kliczkę (ur. 1943 r. Sporniak, gm. Wojciechów), który 8 grudnia 2012 r. zademonstrował grę na ligawie podczas I Turnieju Nalewek Domowych Gminy Konopnica. Była to pierwsza 
publiczna prezentacja gry na Lubelszczyźnie, poprzedzona wykładem poprzedzonym przez autorkę.

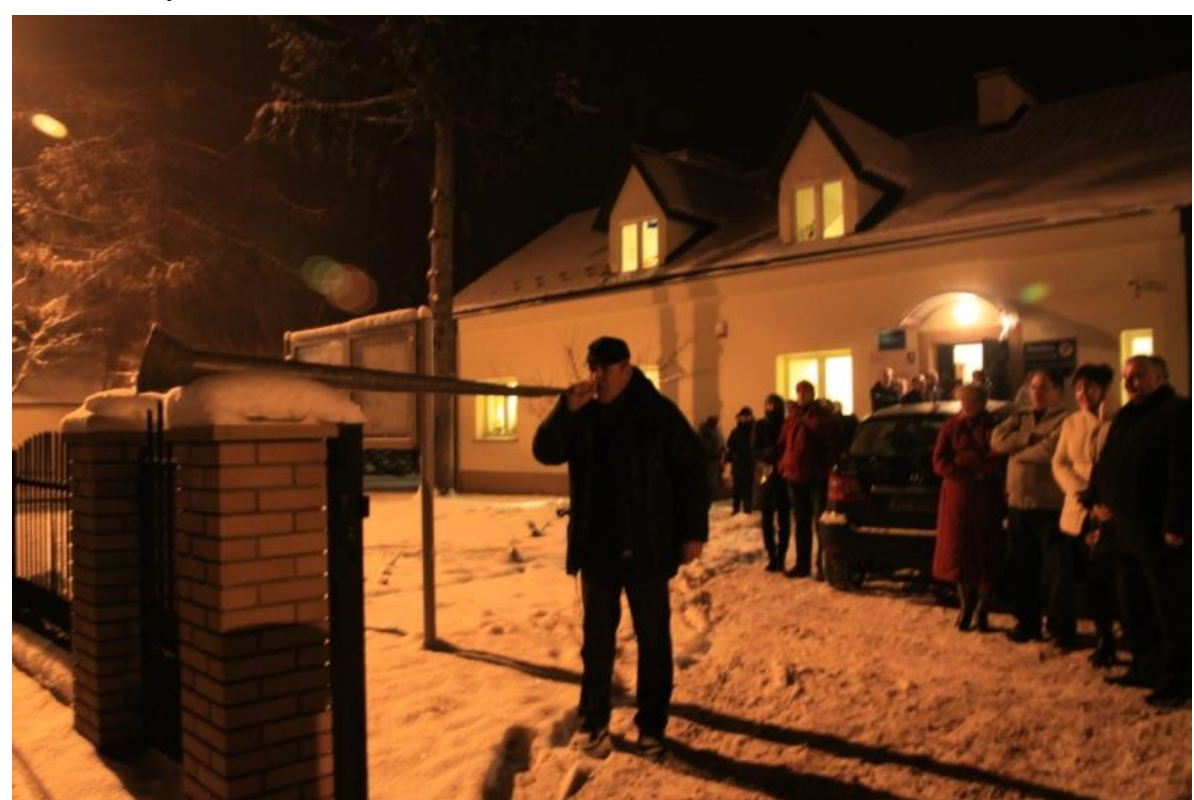

Fot. 1 Motycz Tadeusz Kliczka 8 grudnia 2012, autorka fotografii Agata Kusto

Po śmierci Tadeusza Kliczki w roku 2014 instrument przepadł w prywatnych zasobach rodziny a próby jego odzyskania dla społeczności nie powiodły się do chwili obecnej (Kusto 2017: 3).

Od tego czasu w gminie Konopnica przeprowadzono szereg działań, które miały na celu zbadanie stanu zachowania tradycji lub pamięci o niej wśród mieszkańców oraz próbę znalezienia chętnych do podtrzymania tradycji. Były to spotkania z mieszkańcami o charakterze edukacyjnym, artykuły w prasie lokalnej, ogłoszenia parafialne i prywatne rozmowy z mieszkańcami. Jak się okazało, niektórzy nie kojarzyli nazwy instrumentu ze zwyczajem lub też nigdy go nie widzieli. Impulsem do wzmożonych działań okazał się zakup nowego instrumentu na targowisku instrumentów zorganizowanym $\mathrm{w}$ ramach Ogólnopolskiego Festiwalu Kapel i Śpiewaków Ludowych w Kazimierzu w 2016 r. Na decyzji o zakupie instrumentu zaważyło kilka czynników, wśród których znaczącą rolę odegrał festiwal, jako miejsce spotkań z tradycyjnymi muzykami, ich repertuarem i instrumentami. Przyczyniła się także obecność Piotra Dorosza, etnomuzykologa, trębacza, pracownika IS PAN, który pomógł w wyborze dobrze brzmiącego instrumentu. Ostatecznie członkowie Zespołu Śpiewaczego „Rola” wraz z towarzyszącymi mieszkańcami gminy sfinansowali zakup instrumentu $z$ funduszu sołectwa Sporniak. W tym wypadku był to efekt działań promujących potrzebę reaktywacji zwyczaju i wrażliwości społecznej władz sołectwa. W prasie lokalnej zamieszczano bieżący stan informacji o zwyczaju oraz apelowano do mieszkańców o przekazywanie wszelkich jego przejawów na terenie gminy Konopnica (Sulisz 2017: 18). Instrument zakupiono od Eugeniusza Szymaniaka (ur. 1947, Dzierzby Włościańskie, gm. Jabłonna Lacka), który jest uznanym i czynnym budowniczym instrumentów oraz legaczem. Od wielu lat Szymaniak $\mathrm{z}$ sukcesem bierze udział w konkursach gry na ligawie, gdzie prócz 
prezentacji swych umiejętności wykonawczych i gawędziarskich wystawia do sprzedaży nowo wykonane instrumenty. Podczas ostatniej XXIII edycji konkursu gry na ligawkach „Adwentowe Granie”, która odbyła się 8 grudnia 2018 r. w Siedlcach wystąpiło 40 uczestników a Eugeniusz Szymaniak otrzymał I nagrodę.

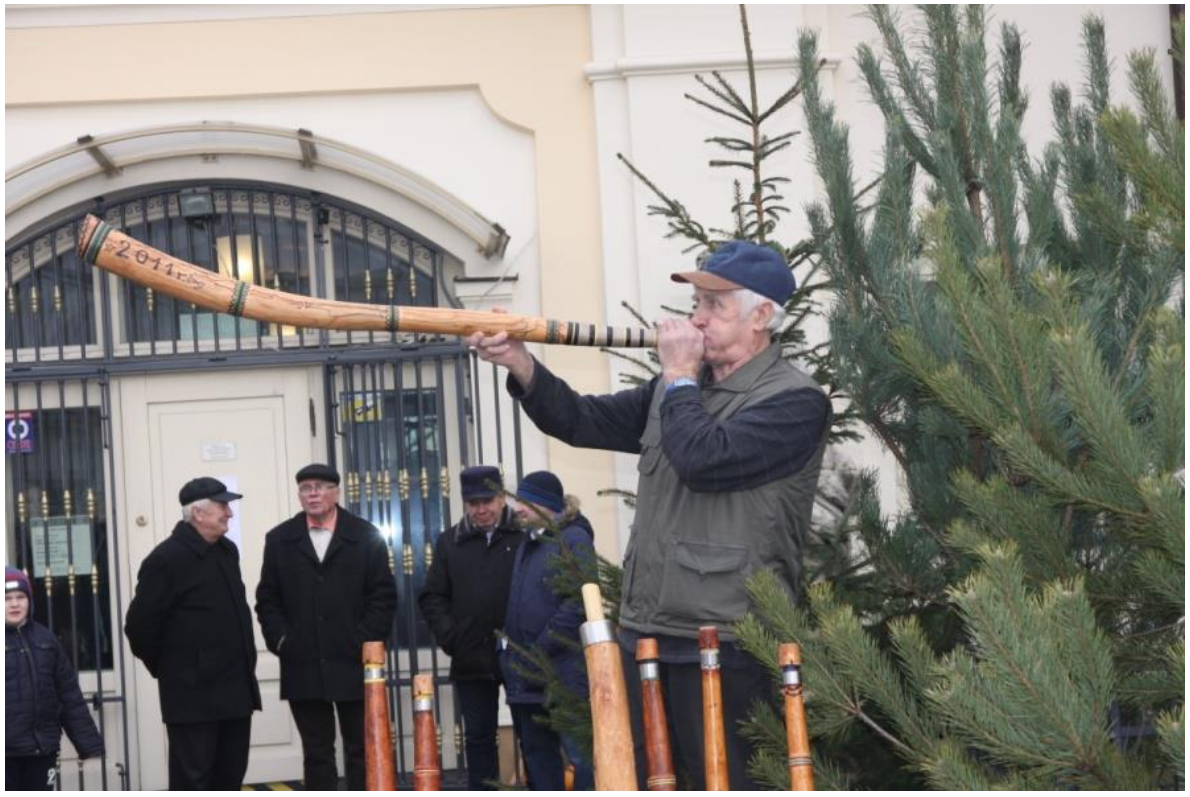

Fot. 2 Eugeniusz Szymaniak, Siedlce 2018, autorka fotografii Agata Kusto

Aktywność estradową Eugeniusz Szymaniaka odnotowuje także Piotr Dahlig. Są to występy i prezentacja wykonanych instrumentów w Ciechanowcu i Siedlcach (Dahlig 2003: 256, 292, 298). Szymaniak jest reprezentantem żywego i chętnie praktykowanego zwyczaju gry na ligawie w kilkunastu miejscowościach powiatu Sokołów Podlaski. Poświadczenia jego istnienia na tym terenie odnajdziemy w wypowiedziach mieszkańców tych okolic, zdeponowanych w Pracowni „Archiwum Etnolingwistyczne” UMCS (Kolonia Wieska, gm. Jabłonna Lacka, TN UMCS 727B/9; Dzierzby, gm. Jabłonna Lacka, TN UMCS 729A/13).

W wigilię pierwszej niedzieli adwentu 2017, w Domu Kultury w Motyczu miało spotkanie robocze. Wykład Piotra Dorosza poświęcony obrzędowej grze na instrumencie zwanym „ligawą" wsparty był pokazem gry oraz omówieniem sposobów wykonywania tego instrumentu. W spotkaniu uczestniczyli: dr hab. Tomasz Rokosz (Instytut Muzykologii KUL), kulturoznawca i muzyk, dr Agata Kusto (Instytut Muzyki UMCS), inicjatorka wydarzenia oraz mieszańcy gminy. Jednym z nich był Mieczysław Kanadys (ur. 1958, zam. Motycz Stara Wieś), który podjął się kontynuowania otrębywania adwentu ze względu na pamięć o tradycjach rodzinnych. Gra na ligawie była obecna w rodzinie Kanadysów od kilku pokoleń. Grał zarówno ojciec Mieczysława, Józef Kanadys (ur. 1926, Motycz), jak i dziadek noszący to samo imię, Józef Kanadys (ur. 1900, Motycz). W efekcie, w czasie adwentu 2017 w Motyczu Starej Wsi rano i wieczorem rozlegał się dźwięk ligawy (Kusto 2017: 13). 


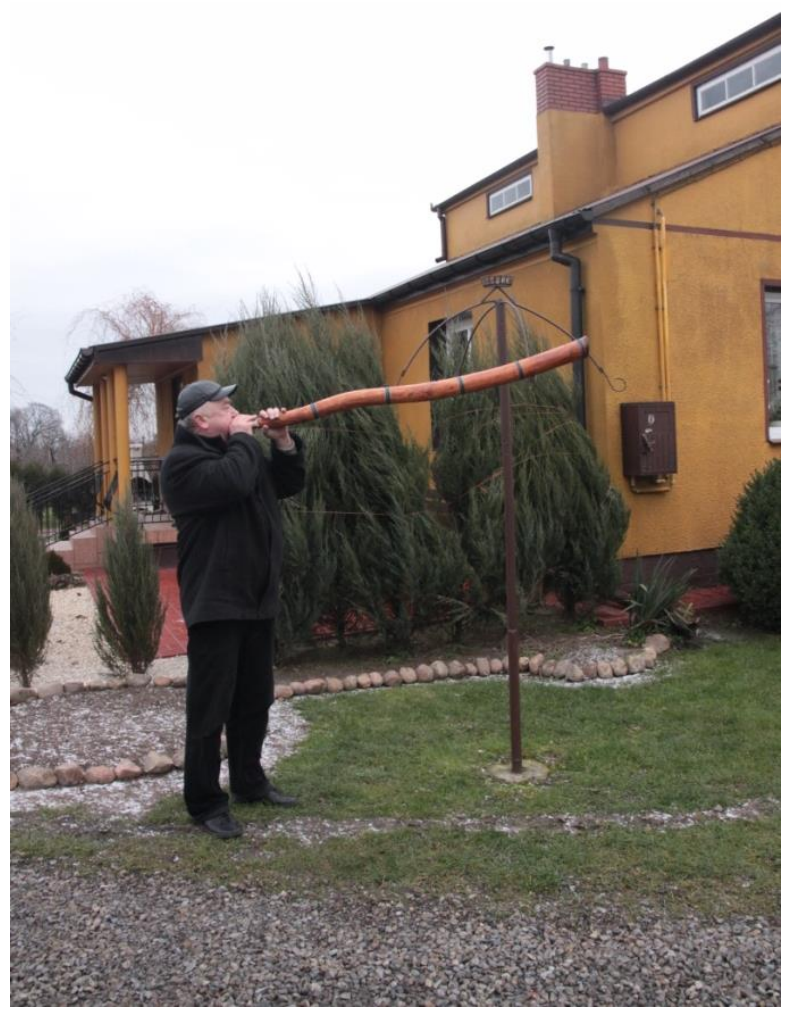

Fot. 3 Mieczysław Kanadys, Motycz Stara Wieś 2017, autorka fotografii Agata Kusto

Ożywienie zwyczaju stanowiło podstawę do dalszych poszukiwań, które mimo starań wielu osób nie przynosiły oczekiwanych rezultatów. Powszechnie uważano, że taki zwyczaj istniał w Motyczu i okolicach, mieszkańcy potwierdzali obecność ligawy w adwencie, lecz nie przywiązywano do tego specjalnego znaczenia, traktując grę na ligawie jako relikt przeszłości, mało istotny dla dzisiejszego człowieka. Fundamentalną rolę w pozyskiwaniu informacji od mieszkańców Motycza pełniła i pełni obecnie Anna Niedziałek, córka Czesława Maja z Motycza. Dzięki jej autochtonicznemu pochodzeniu i wytrwałości początek 2018 roku zaowocował odnalezieniem dwóch instrumentów, z których jeden można określić jako ligawę lubelską (Niedziałek 2018: 15).

Pierwszy odnaleziony instrument pochodzi od Stanisława Tomasika (ur. 1961, Motycz) zamieszkałego w Motyczu II Kolonia, który wspominał, że jego ojciec, Aleksander Tomasik (1935-2008) wynosił w adwencie ligawę pod studnię, polewał wiadrem wody i grał gdy napęczniała i się uszczelniła. Stanisław Tomasik wspomina także Franciszka Jakubczaka (1943-1997), który przychodził do ojca, aby pograć na ligawie (Niedziałek 2017, Kusto 2018a). Instrument, który przez kilkadziesiąt lat przeleżał w domostwie Stanisława Tomasika został wykonany z lekkiego drewna drzewa liściastego (wierzba lub klon jesionolistny), posiada ustnik z drewna twardego (grab lub brzoza) uszczelniony kawałkiem szmatki. Stan instrumentu i rodzaj drewna został wstępnie określony przez Ryszarda Orysiaka, konserwatora Muzeum Lubelskiego w Lublinie z sugestią pilnej konserwacji. Wymiary instrumentu: dł. 109 cm; śr. wlotu $3,8 \mathrm{~cm}$; śr. wylotu $-6,5$ na 8,5 cm; ustnik - dł. 9,8 cm; śr. wlotu $-2 \mathrm{~cm}$. 


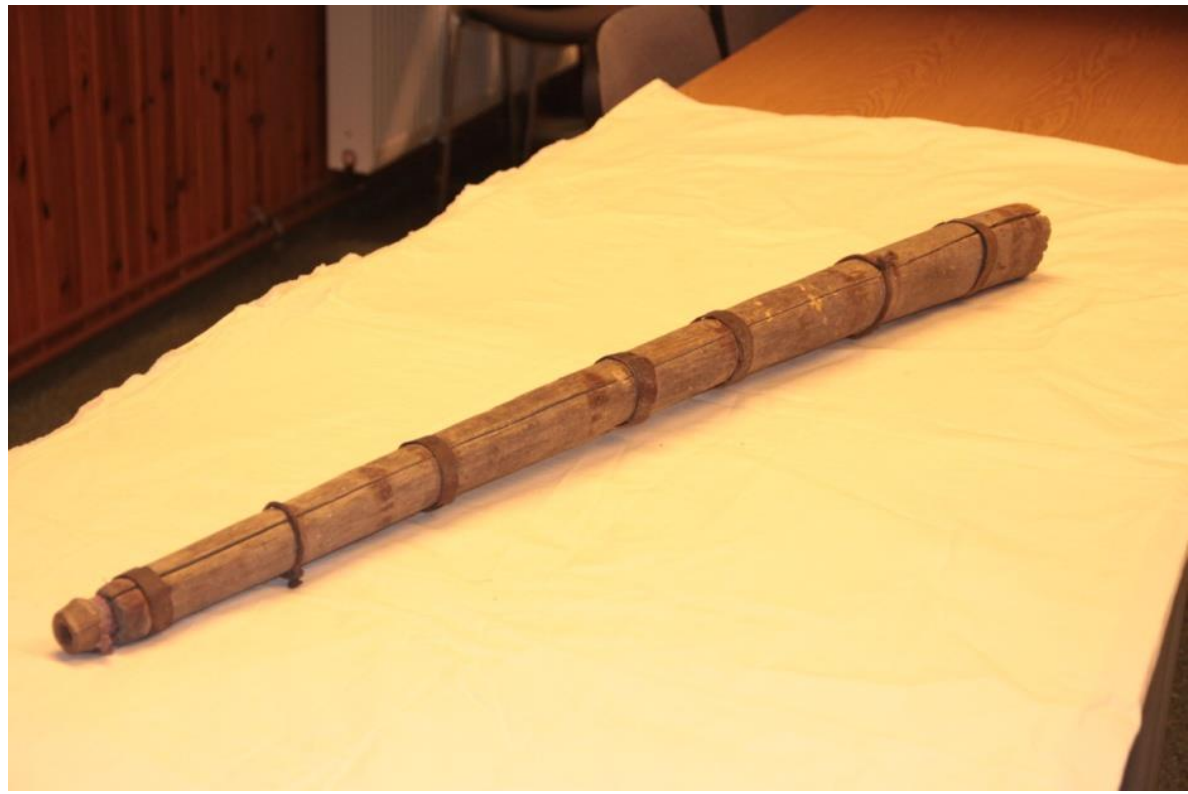

Fot. 4 Ligawa Aleksandra Tomasika z Motycz II Kolonii, autorka fotografii Agata Kusto

Instrument został przekazany do Domu Kultury w Motyczu gdzie oczekuje na konserwację. Drugim instrumentem okazała się ligawa przechowywana u Waldemara Maja, którą Władysław Maj zakupił podczas wyjazdów z Kapelą Wojciechowską w latach $80 . \mathrm{XX}$ w. Obecnie instrument pozbawiony jest obręczy metalowych.

Aktualnie udało się potwierdzić grupę osób, które w przeszłości grały na ligawie, tj. Adam Jośko (1925-2008, zam. Motycz Wróble), Ignacy Kowalczyk (Motycz Skubicha) i Jan Piwowarski (1944-1987, zam. Motycz Skubicha), Tadeusz Piwowarski (Motycz Góry) i niejaki Olszak. Ustalono też, że Bolesław Piwowarski, którego Jan Piwowarski był wnukiem, jako stolarz wykonywał również ligawy (Niedziałek 2017).

Odnalezione instrumenty są materialnym poświadczeniem obecności zwyczaju, jednakże ciągłość jego przekazywania a więc gry i sposób wyrobu instrumentu zostały zerwane. Obecnie trwają starania nad zaktywizowaniem mieszkańców gminy Konopnica oraz sąsiednich gmin do otrębywania adwentu. Pomocne są działania o zasięgu ogólnopolskim, które przenoszą lokalne zwyczaje na poziom współczesnych przeglądów, festiwali i różnorodnych form warsztatowych. Dają szansę na obudzenie zainteresowania wśród dzieci i młodzieży. Znaczenie współczesnego ruch festiwalowego dostrzegł już Piotr Dahlig, określają konkursy gry na ligawce mianem „współczesnego laboratorium tradycji” (Dahlig 2003: 194). Ożywienie tradycji, sukcesywnie wzrastało od roku 1974, kiedy Kazimierz Uszyński zorganizował w Ciechanowcu pierwszy konkurs gry na ligawkach. Kolejnym kamieniem milowym stał się zainicjowany przez Wandę Księżopolską siedlecki konkurs, od roku 2001 organizowany przez Muzeum Regionalne w Siedlcach. Echa działań konkursowych odbijają się także w gminie Konopnica. W dniu 9 grudnia 2018, co przypadło w drugą niedzielę adwentu, przed kościołem pw. MB Anielskiej w Motyczu zorganizowano pokaz gry na ligawie. Uczestnicy mszy św. po, skończonej liturgii mogli usłyszeć i zobaczyć zarówno ligawę jak i legującego gracza. 
$\mathrm{Na}$ instrumencie wykonanym przez swego mistrza-budowniczego, Andrzeja Klejzerowicza zagrał Lubomir Ziółek, mieszkaniec Krężnicy Jarej. Jest on laureatem Ogólnopolskiego Konkursu Gry na Instrumentach Pasterskich w Ciechanowcu w roku 2017, uczniem Szkoły Muzycznej I i II stopnia im. T. Szeligowskiego w Lublinie, w klasie waltorni Marka Młynarczyka. Gra na wielu instrumentach, muzykując wraz $\mathrm{z}$ rodziną w uznanej folkowej kapeli Drewutnia. Jest także uczestnikiem programu „Szkoła mistrzów budowy instrumentów ludowych” - edycja 2018 r. Program został powołany w roku 2012 przez Instytut Muzyki i Tańca a jego założeniem jest nauka i upowszechnianie praktycznych umiejętności budowy polskich instrumentów ludowych oraz wiedzy o ich roli w kulturze Polski metodą bezpośredniego przekazu mistrz-uczeń. Lubomir w ramach programu pod okiem Andrzeja Klejzerowicza wykonał własny instrument bezustnikowy (Kusto 2018b: 26-27). Adwentowe granie w Motyczu było inspiracją do spotkania zorganizowanego 13 grudnia 2018 r. przez Stowarzyszenie Twórców Ludowych w ramach Lubelskiej Sceny Tradycji. W spotkaniu „Dźwięki Adwentu czyli powrót lubelskiej ligawki” udział wzięli Anna Niedziałek, Agata Kusto oraz Lubomir Ziółek, który na zakończenie zalegował na Placu po Farze.

Na rok 2019 zaplanowano i zrealizowano działania warsztatowe, w ramach których Lubomir Ziółek wraz z miejscowymi uczestnikami budował instrumenty według przekazów źródłowych z Motycza i okolic. Zainteresowanie i pasja młodego instrumentalisty dały znakomite efekty. Podczas warsztatów organizowanych przez Gminny Ośrodek Kultury i Sportu w Niedrzwicy Dużej, które także prowadził Andrzej Klejzerowicz, prócz Lubomira Ziółka wziął udział młody mieszkaniec Motycza, Przemysław Żarnowski. Wiadomo, że obecnie motyczanin doskonali się w zakresie samodzielnego wyrobu ligaw, jak też gry na nich, co miało miejsce podczas XXIV edycji Adwentowego Grania w Siedlach w roku 2019.

Powyższy przegląd dotychczasowy źródeł i wydarzeń ma na celu zdefiniowanie problemów jakie rodzi dzisiaj kontynuowanie tradycji muzycznych i próba ich rekonstrukcji jak to ma miejsce w Motyczu. Stąd w tekście zostały pominięte szczegółowe zagadnienia związane z geograficznym rozprzestrzenieniem zwyczaju czy $\mathrm{z}$ danymi dotyczącymi udokumentowanych instrumentów muzycznych. Dzisiejszy stan wiedzy pozwala stwierdzić, że Lubelszczyzna w znacznie szerszym stopniu, niż jak dotąd ustalono, była obszarem żywej tradycji otrębywania adwentu. Praktyka wyrobu instrumentu i gry na nim najpewniej przeniosła się z terenów Podlasia, rozprzestrzeniając się na teren Powiśla Lubelskiego, szczególnie w gminach Puławy, Garbów, Abramów, Wąwolnica, Końskowola i Konopnica. Pojedyncze przekazy z miejscowości bardziej odległych mikroregionów, jak Świerże, gm. Dorohusk, Olchowiec, gm. Obsza czy Ruda Żurawiecka, gm. Lubycza Królewska (Nowak 2003: 48) domagają się badań uzupełniających. Ligawy występujące na Lubelszczyźnie to w większości instrumenty, których długość mieści się $\mathrm{w}$ przedziale od 110 do $150 \mathrm{~cm}$ i zasadniczo wszystkie wyposażone są w ustnik drewniany wyrabiany z twardszego rodzaju drewna. Tak jak na Podlasiu i Mazowszu, ligawy uszczelniano smołą i łączono wyżłobione połówki opaskami z drutu bądź metalu. W katalogu ligaw lubelskich szczególne miejsce zajmuje blaszana ligawa Władysława Maja, która obecnie uznana jest za zaginioną. Na uwagę zasługuje kontekst gry, a wiec funkcjonowanie jedynie podczas adwentu. Wzmianki o wykorzystaniu ligawy podczas Wielkanocy, wesela czy w celach sygnalizacyjnych sa marginalne $\mathrm{w}$ stosunku do liczniejszego identyfikowania ligawy ze wspomnianym okresem liturgicznym. Badania nad muzycznymi aspektami gry są uzależnione od tego czy w przyszłości praktyka ogrywania adwentu upowszechni się w Motyczu i okolicach oraz czy mieszkańcy, jako depozytariusze tradycji zatroszczą się o własną tradycję. 


\section{Bibliografia}

Chmara, J. (1937). Lubelska Pieśń Ludowa, cz. 1. Lwów-Warszawa: Książnica Atlas.

DAHLIG, P. (2003). Muzyka adwentu. Mazowiecko-podlaska tradycja gry na ligawce. Towarzystwo Naukowe Warszawskie: Warszawa.

KAMIŃSKI, W. (1971). Instrumenty muzyczne na ziemiach polskich. Zarys problematyki rozwojowej. Polskie Towarzystwo Muzyczne: Kraków.

KARWICKA, T. ( 1959). Na lubelskiej wsi. „Poznaj Swój Kraj”, nr 10, 10-11.

Komsta, K. (1980). Folklor bożonarodzeniowy Michatówki i Sosnówki. Lublin 1980. Praca magisterska pod kierunkiem doc. dr. hab. J. Bartmińskiego UMCS.

KOTER, Z. (2018). Wywiad na temat ligawy przeprowadzony z Zenonem Koterem przez Agatę Kusto w dn. 15.11.2018.

KOTER, Z., KUSTO, A. (2011). Muzyka instrumentalna. Instrumentarium - wykonawcy repertuar. W: J. Bartmiński (red.), Polska pieśń i muzyka ludowa. Źródła i materiaty. T. 4 Lubelskie (s. 373). Lublin: Wydawnictwo Muzyczne Polihymnia.

Kusto, A. (2017). Aby do Gód, aby do Gód ... „Echo Konopnicy”, nr 10-12, 3. Pozyskano z: http://www.konopnica.eu/wp-content/uploads/2015/11/EK-10-12-2017-net.pdf.

Kusto, A. (2018a). Wywiad przeprowadzony przez Agatę Kusto ze Stanisławem Tomasikiem w dn. 28 listopada 2018 r. w Motyczu.

Kusto, A. (2018b). Ligawa symbolem adwentu. „Echo Konopnicy”, nr 10-12, 26-27. Pozyskano z: https://konopnica.eu/wp-content/uploads/2018/12/Echo-Konopnicy-52018_NET.pdf.

Lasota, P. (2011). Czesław Maj. Granie na ligawach - opowieść biblijna ttumaczaca zwyczaj grania. Teatr NN. Archiwum Programu Historii Mówionej. Pozyskano z http://biblioteka.teatrnn.pl/dlibra/Content/46242/HM_Maj_Czeslaw_2011 _03_24_Granie_na_ligawach__opowiesc_biblijna_tlumaczaca_zwyczaj_grania.pdf.

LEWIŃSKA, T. (2001). Polskie ludowe instrumenty muzyczne. Katalog zbiorów Państwowego Muzeum Etnograficznego w Warszawie. Warszawa: Państwowe Muzeum Etnograficzne.

MaJ, Cz. (2008). Protokół z badań terenowych $w$ m. Sporniak, gm. Konopnica z dn. 27.02.2008. Instytut Muzyki UMCS.

MALINOWSKA, J. (1997). Ligawa podlasko-mazowiecka a ligawa lubelska. Lublin 1997. Praca magisterska pod kierunkiem dr. Z. Kotera UMCS.

NiEDZIAlEK, A. (2017). Wstępne rozeznanie terenowe przeprowadzone przez Anne Niedziałek na terenie Motycza.

NiEdZIAŁEK, A. (2018). Poszukiwania ligaw przynosza efekty... „Echo Konopnicy”, nr 12, 15. Pozyskano z http://www.konopnica.eu/wp-content/uploads/2015/11/EchoKonopnicy-1-2018_ostateczna-wersja_net.pdf.

NowaK, J. (2003). Adwent $i$ Boże Narodzenie $w$ regionie tomaszowskim. Studium religijności ludowej. Lublin: Towarzystwo Naukowe Katolickiego Uniwersytetu Lubelskiego.

PETERA, J. (1986). Obrzędy $i$ zwyczaje ludowe $w$ okresie Bożego Narodzenia. W: J. Bartmiński, Cz. Hernas (red.), Kolędowanie na Lubelszczyźnie. Polskie Towarzystwo Ludoznawcze: Wrocław. 
SACHS, C. (1989). Historia instrumentów muzycznych. Przełożył: Stanisław Olędzki. Polskie Wydawnictwo Muzyczne: Kraków.

SoBIESKA, J. (2006). Polski folklor muzyczny. W: P. Dahlig (red.), Materiaty pomocnicze dla nauczycieli szkół i ognisk artystycznych. Wyd. III rozszerzone. Warszawa: Centrum Edukacji Artystycznej..

SOBIESKI, M. (1973). Instrumenty ludowe na wystawie polskich instrumentów. W: L. Bielawski (red.), Polska muzyka ludowa i jej problemy (167-178). Kraków: Polskie Wydawnictwo Muzyczne.

Sulisz, M. (2017). Jak to było z ta ligawa - historia. „Echo Konopnicy”, nr 10-12, 18. Pozyskano z: http://www.konopnica.eu/wp-content/uploads/2015/11/EK-10-12-2017net.pdf.

SZYMAŃSKA, J. (2016). Pieśni i obrzędy doroczne. Obrzędy zimowe. W: L. Bielawski (red.), Polska pieśń i muzyka ludowa. Źródta i materiały, t. 5 Podlasie, (156-165), wyd. II rozszerzone. Warszawa: Instytut Sztuki PAN.

WRONA, S. (1993). Nagranie z roku 1993, TN UMCS 837A. 


\section{Agata KuSto \\ LigaWA PLAYING IN THE LUBLIN REGION: CONTEMPORARY DISCOVERIES AND CONTINUATION OF A LOCAL MUSICAL PRACTICE}

The article presents the most recent research on the reactivation of an old musical tradition in the Lublin region, called "trumpet blowing at Advent." This custom is connected with playing an aerophone named ligawa and with a local practice of making this instrument. The ligawa or ligawka has an eventful history of presence in Poland. In the folk culture, it is associated with the signalling function widespread among shepherds in the mountains. The current research is focused on the ritual practice connected with the liturgical period of Advent in the Roman Catholic Church. The presence of this custom has been confirmed in the neighbouring regions of Mazowsze and Podlasie.

The author reviews the ethnographical descriptions of the ritual ligawa playing in the Lublin region and compares them with the results of her own field research conducted in villages near Lublin since 2008. The author attempts to answer the question to which extent contemporary societies are able to revive and practise on a regular basis forgotten rites of the musical character. In the study contains examples of documented instruments, descriptions of instrument playing circumstances and profiles of the depositaries of this tradition: ligawa players and makers from the Lublin region.

The discussed subject is part of a broader discussion on the issues of preserving and safeguarding intangible cultural heritage and - due to its topicality - requires continuation and comparison with similar undertakings in the field of revival of local musical practices. 